
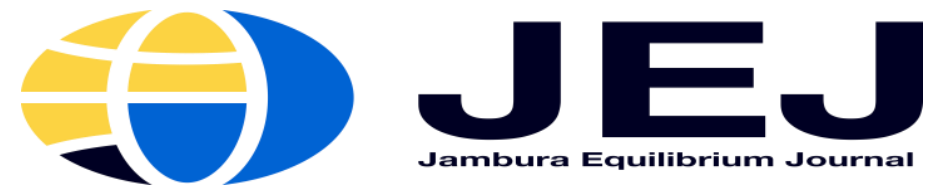

Volume 3. Issue 1. January 2021

P-ISSN 2655-9110

E-ISSN 2656-0445

http://ejurnal.ung.ac.id/index.php/equij

\title{
Analysis of Financing Prospects of Mandiri Syariah Bank (BSM) in Pemalang
}

Ruchul Qhisti Izzati ${ }^{1}$, Nining Nurhasanh ${ }^{2}$

Sekola Tinggi Ekonomi Islam SEBI, Jawa Barat, Indonesia ${ }^{1,2}$

Abstract: The author conducted research on the Prospect Analysis of Bank Syariah Mandiri (BSM) in Pemalang City, the majority of which are inhabited by Muslims. So that the urgency of establishing a Sharia Financial Institution is very important. Because if it is allowed, the community will be entangled in transactions that are prohibited in Islam, namely usury. The aim is to analyze the prospects for Bank Syariah Mandiri (BSM) in Pemalang City and to find out how much potential the establishment of Bank Mandiri Syariah in Pemalang City. The research method used is a descriptive exploratory research model with a quantitative approach and analysis with a qualitative approach. The conclusion of this study is that based on the macroeconomic aspect, the establishment of Bank Syariah Mandiri in Pemalang City has a very big opportunity to be established. In the aspect of operational analysis, there is an appropriate place for the establishment of Bank Syariah Mandiri in Pemalang City. The right place to set up Bank Syariah Mandiri is located at Jalan Jend. Sudirman Mulyoharjo, Pemalang Regency. And in the market aspect, the authors conducted a survey on SMEs in Pemalang City. And the result is 79\% of SMEs in Pemalang City are interested in the existence of Bank Syariah Mandiri.

Keywords: Financing; Prospect; Prospect Analysis

\section{INTRODUCTION}

The potential for establishing Bank Syariah Mandiri (BSM) is enormous, however, the strategy for its establishment has not been discussed. Moreover, banking plays a major role in the needs of the people who want to develop their business in order to improve the economic sector. Because in addition to managing savings and loans from third parties, banks also distribute small and medium business loans in various economic sectors, such as the economic sector, such as the agriculture, mining, industry, electricity, construction, trade, transportation, business services, social services and others (BPS, 2013).

The understanding of sharia economics as an alternative may be due to the fact that this system is one that has a competitive advantage and reflects a new, innovative model in the business world in the late era. The world of finance and managerial which is considered to have certain advantages and advantages. These advantages can at least be seen from the appreciation of the global business community who have begun to look at this system as an option and even become the superior choice for their business. Apart 
from that, regardless of whether they agree or not, it turns out that when the crisis hit this country, sharia institutions were relatively able to survive and even develop. In fact, on the one hand, other conventional financial institutions have collapsed or gone bankrupt, and in fact subsequently become a burden to the state (Solahuddin, 2008).

In research (Dhakwan, 2018) in Pemalang City, the majority of the population is inhabited by Muslims. So that the urgency of establishing a Sharia Financial Institution is very important. Because if it is allowed, the community will be entangled in transactions that are prohibited in Islam itself, namely usury. The majority of the population of Pemalang city is Muslim with the number of followers reaching $30.54 \%$ of the total population. However, there is an interesting thing that has become a problem with the distribution of funds for Commercial Banks and Islamic Commercial Banks in Pemalang City. Commercial Banks and Sharia Commercial Banks in Pemalang City channel their financing funds which are mostly not for SMEs. This is one of several opportunities for the establishment of Bank Syariah Mandiri. Funds disbursed to Commercial Banks and Islamic Commercial Banks are mostly channeled to the macro sector, such as in the industrial sector, agricultural sector and trade sector. However, the micro sector, such as the business services sector and the transportation sector, is still lacking in channeling financing funds from banks.

The definition of prospect analysis according to Jumingan in the journal (Alfiyah, 2015) is "a comprehensive assessment to assess the success of a project, and a project feasibility study aims to avoid investing too much for activities that are not profitable." Analysis of the project or business prospect is an activity to evaluate, analyze, and assess whether or not a business project is feasible or not. In general, the purpose of conducting an analysis, especially for investors, is to avoid over-investing or investing too large for a project or business activity that turns out to be unprofitable.

Prospect analysis in $\mathrm{BSM}$ is to assess the potential of the area for investment in the development of micro banking (BSM) using historical data from a certain period and analyzed descriptively (Da'wah, 2013, p. 3). In conducting a business feasibility study, there are several aspects that must be considered, namely macroeconomic analysis, SWOT analysis, human resource aspect analysis, operational aspect analysis, market aspect analysis, and financial aspect analysis.

Definition of financing according to Ridwan (2007) financing based on Sharia principles is the provision of funds based on a loan agreement between a bank and another party, provided that the borrower is required to pay off the debt after a certain period of time by including the profit sharing. Meanwhile, cashmere also explains that financing is the provision of money or an equivalent bill, based on an agreement or agreement between the bank and another party which requires the financed party to return the money or bill after a certain period of time in exchange for profit sharing. Thus the definition of financing is the provision of funds by the bank channeled to another party with the terms of return with a return or sharing. In financing, there is a contract that must be carried out by two parties, namely Shahibul Mall and Mudarib. According to Muhammad, a financing contract is the binding of two parties with an agreement, including an agreement on the length or time of the contract. According to Kasmir (2004: 75-76) the elements contained in financing are:

1. Trust

That is the confidence of the donor party that the funds given will really be returned in the future. 
2. Deal

The agreement is manifested in the form of an agreement where each party signs their respective rights and obligations.

3. Time period

The term includes the long or short period in which the funds must be returned.

4. Risk

The risk of loss can be caused by two, namely the intention of the customer who does not want to return the funds, even though the customer is able not to return the funds, the customer is able to return it and because the occurrence of a disaster or accident so that it is really unable to return.

5. Remuneration

As a result of the provision of financing or credit, the fund provider expects a certain amount of return on benefits.

The provision of financing by banks is not only for seeking profit, but from the financing provided by the bank also provides benefits for customers and the economy. Indirectly, the more financing is channeled, the people's economy will also experience an increase. Thus, financing has a very good function for the community.

According to Ridwan (2007: 96-97) in general, financing has the following functions:

1. Increase the usability of money

The funds placed by shaibul maal in Islamic banks are in the form of savings, deposits, current accounts and other forms. The funds will be increased for the bank's efficiency so as to increase productivity

2. Increase the usability of goods

With the help of Islamic banks, producers can increase their production capabilities, processing raw materials into finished goods so as to change and increase the usability of goods. The distribution of manufactured goods can reach consumers who need it

3. Increase the circulation of money Financing channeled through various accounts of entrepreneurs can create a circulation of demand deposits and currency.

4. Increase business enthusiasm

The problem of limited capital, in starting or developing a business can be overcome with financing. People who have the potential to develop their business can cooperate with Sharia banks to meet their business capital needs.

5. Maintain social economic stability In less normal economic conditions, problems that often arise include boosting inflation, sluggish export drive, low investment value and other macroeconomic problems.

According to Arifin $(238,2002)$, the financing procedure is a description or method for the implementation of a financing activity. This definition emphasizes that procedure is how to carry out an activity from crew to completion. So that with the procedure can help humans in carrying out certain activities. According to Kasmir $(95,2004)$ the purpose of providing credit is to ensure the creditworthiness of a credit, whether it is accepted or rejected.

\section{METHODOLOGY}

\section{Types of research}

This research was conducted using descriptive explanatory research model with a quantitative approach and analysis with a qualitative approach. (Da'wah, 2013). In essence, this research seeks to find facts in depth to answer the question whether the establishment of Bank Syariah Mandiri in Pemalang City is feasible in terms of operational technical aspects and economic, financial and social feasibility. 


\section{Type of Data}

The types of data used in this study are primary data and secondary data. Primary data is data taken directly from the source. Primary data from this study were obtained from respondents' answers, namely information about the behavior, characteristics and public perceptions of Islamic banking. (Nevita, 2015). As well as secondary data, which is taken from available data or raw data. The data used is still in the form of raw data (raw data) sourced from Pemalang City BPS. Raw data from BPS is processed in 2016. In addition to using qualitative data from BPS, the author also uses qualitative data as supporting data taken from various agencies, literature studies, or other references (journals, books, articles of previous research results, and internet searches) related to the scope of research problems.

\section{Object of research}

In order for research to remain focused on one problem, it requires an object of research that is in accordance with the discussion. The object of this research is one of the cities in Central Java, namely Pemalang City. And this discussion focuses on the analysis of the prospect of Bank Syariah Mandiri loan financing in Pemalang.

\section{Data Collection Techniques}

The data collection technique used by the author is data collection techniques with field studies and documentation studies. The field study here uses interview techniques. Interviews are a way of collecting data or information by directly meeting the informants, with the aim of getting a complete picture of the topic under study (Bungin, 2007, p. 3). Documentation study is collecting documents and data needed in a research problem and then studied intensively so that it can support and increase confidence and prove an incident (Satori, 2012, p. 149).

The documentation method is usually used to collect secondary data from various sources, both personally and institutionally. Data such as: financial reports, personnel recapitulation, organizational structure, regulations, production data, wills, curriculum vitae, company history, and so on, are usually available at the research location. Final researchers copy as needed. In general, the data obtained by means of documentation is still very raw because between one information and another is scattered, even sometimes it is difficult to understand what the data contains. For this reason, researchers must organize the data systematics in such a way and ask for further information from the first data collector.

The data collection techniques used by the author are field study data collection techniques and documentation studies. And also use documentation study data collection techniques, because documentation studies also play a major role in qualitative research. In this study, the authors collect and use the necessary data as a support in conducting this research.

\section{Technical Data Analysis}

Data analysis techniques are what analysis techniques will be used by researchers to analyze data that has been collected, including testing. The data collected is determined by the research problem which at the same time reflects the characteristics of the study objectives whether to explore, compare, or test hypotheses (Sanusi, 2011). Data analysis is translated as a process of simplifying data and presenting data by grouping them in an 
easy-to-read form. Data analysis can also be interpreted as a form of categorization, organization, manipulation, and data ranking to obtain answers to research questions. In this study the data and information obtained will be analyzed using descriptive methods which aim to describe precisely the characteristics of a particular individual, condition, symptom, or group, or to determine the frequency or spread of a symptom or the frequency of a certain relationship between a symptom and other symptoms in the object of research. Quantitative data obtained from BPS is still in the form of raw data, so this data will be processed. This quantitative data processing includes data editing, data transformation (coding), data presentation and hypothesis testing in order to obtain complete data from each object for each variable under study.

\section{RESULTS AND DISCUSSION}

According to Ricard in the Journal (Irawan, 2016, p. 4), SWOT Analysis (SWOT Analysis) includes efforts to identify strengths, weaknesses, opportunities and threats that determine company performance. External information regarding opportunities and threats can be obtained from many sources, including customers, and government documents, suppliers, banking circles, other corporate partners. Many companies use the services of scanning agencies to obtain newspaper clippings, research on the internet and analysis of relevant domestic and global trends.

The strength of Bank Syariah Mandiri Financing in Pemalang City is by conducting a survey on MSMEs in Pemalang City, many MSMEs are interested in the existence of Mandiri Syariah Financing in Pemalang City. Bank Syariah Mandiri is located in a strategic place, namely in Pemalang City Square and in the District with the most MSMEs compared to other districts in Pemalang City.

The weakness in Pemalang City, if Bank Syariah Mandiri was established, was the increased non-performing loans in BSM in Pemalang City, so that it could become a threat to banking companies in Pemalang City. NPL occurs because of nonperforming loans at BSM in Pemalang City. Opportunity at Bank Syariah Mandiri in Pemalang City is that with an increasing population, it will have a positive impact on business development at Bank Syariah Mandiri in Pemalang City. And with so many people starting a trading business, there will be more opportunities for profit.

The threat if Bank Syariah Mandiri in Pemalang City is with existing banking companies, it will become a competitor for the establishment of Bank Syariah Mandiri in Pemalang City. The existence of Bank service products from more attractive competitors will be a threat to business continuity. And with the existence of a bank company that has more adequate capacity and facilities, it can become a threat to Bank Syariah Mandiri financing.

\section{CONCLUSION}

This research is intended to examine the aspects of the Analysis of the Prospect of Bank Syariah Mandiri (BSM) financing in Pemalang City. Based on the description of the analysis results in the previous chapter, the writer conducted research based on several aspects. These aspects are macroeconomic analysis, SWOT analysis, human resource aspect analysis, operational aspect analysis, market aspect analysis, and financial aspect analysis. Based on the macroeconomic aspects of Bank Syariah Mandiri financing in Pemalang City has a very big opportunity to be established. With the support of the economic aspect in Pemalang City, the indicators include 
population, per capita income, inflation rate, number of banks, potential BSM savings, potential BSM deposits, potential BSM credit, potential savings for Commercial Banks and Sharia Commercial Banks, potential deposits for Commercial Banks and Sharia Commercial Banks, and potential credit for Commercial Banks and Sharia Commercial Banks. In the aspect of operational analysis, there is an appropriate place for financing Bank Syariah Mandiri in Pemalang City. The right place to establish Bank Syariah Mandiri financing is located at Jalan Jendral Sudirman No.129 Mulyoharjo Pelutan Pemalang. And in the market aspect, the authors conducted a survey on MSMEs in Pemalang City. And the result is $79 \%$ of MSMEs in Pemalang City are interested in the prospect of Bank Syariah Mandiri financing.

\section{REFERENCES}

Agustin, H. (2017). Sharia Business Feasibility Study. Depok: PT RajaGrafindo Persada.

Ahmad D. (2018). Analysis of the feasibility study of a BPRS Blitar City.

Aman. (2007). Qualitative Research Methodology.

Antonio Syafi'i. (2007). Islamic Banking: From Theory to Practice. Gema Insani in collaboration with Tazkia Cendekia.

Arifin Zainul. (2009). Basics of Sharia Management.

BPS Pemalang City. (2017) Pemalang City in 2017 Figures

Buchori, B. H. (2013). Study on Industrial Performance of BPRS in Indonesia.
Central Java Provincial Government. (2016). The livelihoods of Pemalang subdistrict rural areas. Department of Statistics, B. I. (2015). Gross Regional Domestic Product.

Hainim, Y. Y. (2012). Optimizing the Influence and Existence of Cooperatives as Pillars of Regional Economy. Journal of Economics.

Hosen, M. H. (2008). Islamic Economics Basics. Central Jakarta: Sharia Economic Communication Center.

Kasmir (2012). Banking Management. Rajawali Press.

Kasmir. (2004). Bank Marketing. Kencana. Pemalang Regent. (2013). 2012 Pemalang Regent Accountability Statement Report.

Salman, T. S. (2017). Exploring the Impact of Real Sector Shocks on Islamic Banking in Pakistan: A VECM Approach. Pakistan.

Sania, Z. M. (2016). The effect of TPF, NPL, and CAR on the amount of Persero Banking Credit. Journal of Management Science and Research.

Sanusi, A. (2011). Business Research Methodology. Malang: Salemba Empat Publisher.

Soemitro (2009). Islamic institutions and finance.

Solahudin, I. (2008). Islamic Economic Insights. Insight of Gratitude for Divine Gifts. Garut: ICMI MEDIA Publish.

Sudarsono, H. (2012). Sharia Banks and Financial Institutions. Yogyakarta: ECONISIA.

Taswan (2010). Banking Management. 